\title{
Pharmacological activities of optically pure enantiomers of the $\kappa$ opioid agonist, U50,488, and its cis diastereomer: evidence for three $\kappa$ receptor subtypes
}

\author{
Richard B. Rothman ${ }^{1, *}$, Charles P. France ${ }^{2}$, Victor Bykov ${ }^{1}$, Brian R. De Costa ${ }^{3}$, \\ Arthur E. Jacobson ${ }^{3}$, James H. Woods ${ }^{2}$ and Kenner C. Rice ${ }^{3}$ \\ ${ }^{\prime}$ Unit on Receptor Studies, LCS, NIMH, Bldg. 10-3D41, Bethesda, MD 20892, '2 Department of Pharmacology, University of Michigan \\ School of Medicine, Ann Arbor, MI, and ${ }^{3}$ Laboratory of Medicinal Chemistry, NIDDK, Bethesda, MD 20892, U.S.A.
}

Received 14 April 1989, accepted 6 June 1989

De Costa et al. (FEBS Lett. 223, 335; 1987) recently described the synthesis of optically pure enantiomers of ( \pm )-trans-3,4-dichloro-N-methyl-N-[2-(1-pyrrolidinyl)-cyclohexyl]benzeneacetamide (U50,488). In the present study we examined the in vitro opioid receptor selectivity of $(-)-(1 \mathrm{~S}, 2 \mathrm{~S})-\mathrm{U} 50,488,(+)-(1 \mathrm{R}, 2 \mathrm{R})-\mathrm{U} 50,488$ and ( \pm )-cis-3,4-dichloro-N-methyl-N-[2-(1-pyrrolidinyl)-cyclohexyl]benzeneacetamide (the cis diasteromers of U50,488), as well as their pharmacological activities in rhesus monkeys. Using $\left[{ }^{3} \mathrm{H}\right] 5 \alpha, 7 \alpha, 8 \beta-(-)-\mathrm{N}$-methyl- $\mathrm{N}$-[7-(1-pyrrolidinyl)-1-oxaspiro $(4,5)$ dec-8-yl]-phenyl-benzeneacetamide $\left(\left[{ }^{3} \mathrm{H}\right] \mathrm{U} 69,593\right)$ to label $\kappa$ binding sites of guinea pig membranes, the apparent dissociation constants of the enantiomers of U50,488 were 0.89 and $299 \mathrm{nM}$, for the (S,S) and (R,R) enantiomers, respectively. The (-)-cis and (+)-cis diastereomers had apparent $\mathrm{K}_{\mathrm{d}} \mathrm{s}$ of 167 and $2715 \mathrm{nM}$, respectively. Binding surface analysis of the interaction of $(-)-(1 \mathrm{~S}, 2 \mathrm{~S})-\mathrm{U} 50,488$ with $\kappa$ binding sites labeled by $\left[{ }^{3} \mathrm{H}\right]$ bremazocine resolved two binding sites at which (-)-(1S,2S)-U50,488 had $\mathrm{K}_{\mathrm{d}} \mathrm{s}$ of 30 and $10485 \mathrm{nM}$, respectively. The ( \pm )-cis, (-)-cis and (+)-cis diastereomers of U50,488 $(1 \mu \mathrm{M})$ did not inhibit $\left[{ }^{3} \mathrm{H}\right]$ bremazocine binding. Rhesus monkeys were trained to discriminate ethylketocyclazocine (EKC) and saline. All compounds tested substituted completely for EKC. The order of potency was $(-)-(1 \mathrm{~S}, 2 \mathrm{~S})-\mathrm{U} 50,488>( \pm)-\mathrm{U} 50,488>( \pm)$-cis diastereomer of U50,488 $>(+)-(1 \mathrm{R}, 2 \mathrm{R})-\mathrm{U} 50,488$. In tests of analgesia, $(-)-(1 \mathrm{~S}, 2 \mathrm{~S})-\mathrm{U} 50,488$ was $2-4$ times more potent than $( \pm)$-U50,488, while $( \pm)$-cis diastereomer of U50,488 and ( + )-(1R,2R)-U50,488 were inactive at the highest doses tested $(32 \mathrm{mg} / \mathrm{kg})$. Taken collectively, these data indicate that the pharmacologically active enantiomer of U50,488 is (-)-(1S,2S)-U50,488, and provide preliminary evidence for three subtypes of $\kappa$ binding sites in guinea pig brain.

Opiate receptors; $\kappa$ Opioid receptors; U-50,488; U-69,593; (Enantiomers, cis diastereomer of U-50,488)

\section{Introduction}

( \pm )-Trans-3,4-dichloro-N-methyl-N-[2-(1-pyrrolidinyl)-cyclohexyl]benzeneacetamide (U50,488) is a highly selective agonist at the $\kappa$ opioid receptor (Von Voigtlander et al., 1983). The pharmacological profile of $\kappa$ opioid receptor agonists in-

\footnotetext{
* To whom all correspondence should be addressed.
}

cludes activity as diuretics (Leander, 1983), as anticonvulsants (Von Voigtlander and Lewis, 1988), as analgesics (Von Voigtlander et al., 1983), and perhaps as mu receptor antagonists (Porreca and Tortella, 1987; Sheldon et al., 1987). Other data suggest that $\kappa$ opioid agonists in man are psychotomimetic (Pfeiffer et al., 1986), and that $\kappa$ agonists may be beneficial in the treatment of acute brain and spinal cord injury (Hall et al., 1987). Most studies employing U50,488 have used 
the racemate. The relative contributions of the two enantiomers to the observed pharmacological effects is unknown, and complicates the interpretation of results, especially since it is well known that enantiomers often produce different and sometimes opposite effects (Ariëns, 1987; 1986). For this reason De Costa et al. (1987) synthesized optically pure enantiomers of U50,488.

In our studies we define $\kappa$ binding sites as the residual binding sites remaining after suppression of $\mu$ and $\delta$ binding sites (Kosterlitz et al., 1981). Initial binding experiments using $\left[{ }^{3} \mathrm{H}\right](-)$ bremazocine $\left(\left[{ }^{3} \mathrm{H}\right] \mathrm{BRM}\right)$ to label $\kappa$ binding sites of guinea pig brain indicated that $(-)-(1 \mathrm{~S}, 2 \mathrm{~S})$ $\mathrm{U} 50,488$ was much more potent than $(+)$ $(1 \mathrm{R}, 2 \mathrm{R})-\mathrm{U} 50,488$ in displacing binding (De Costa et al., 1987). In a more detailed study, this was confirmed using $\left[{ }^{3} \mathrm{H}\right] 5 \alpha, 7 \alpha, 8 \beta-(-)-\mathrm{N}$-methyl-N[7-(1-pyrrolidinyl)-1-oxaspiro(4,5)dec-8-yl]phenylbenzeneacetamide $\left(\left[{ }^{3} \mathrm{H}\right] \mathrm{U} 69,593\right)$ to label $\kappa$ binding sites (Lahti et al., 1985; Rothman et al., 1988b). In this paper we examine the interaction of $( \pm)$ cis-3,4-dichloro- $\mathrm{N}$-methyl-N-[2-(1-pyrrolidinyl)cyclohexyl]benzeneacetamide (abbreviated $( \pm)$ cis-I) and its enantiomers (abbreviated $(+)$-cis-I and $(-)$-cis-I) with $\kappa$ binding sites labeled by $\left[{ }^{3} \mathrm{H}\right] \mathrm{U} 69,593$ and $\left[{ }^{3} \mathrm{H}\right] \mathrm{BRM}$. The pharmacological activity of ( \pm )-cis-I and the two enantiomers trans-U50,488 were also studied in rhesus monkeys using a drug discrimination paradigm and a test for analgesia. The results demonstrate that in tests of analgesia and drug discrimination, $(-)-(1 S, 2 S)-$ $\mathrm{U} 50,488$ is more potent than (+)-(1R,2R)$\mathrm{U} 50,488$, and further, although ( \pm )-cis-I substitutes for ethylketocyclazocine (EKC) in the rhesus monkey, it is not an antinociceptive agent.

\section{Materials and methods}

\subsection{Pharmacological studies}

\subsubsection{Subjects}

Four male and two female rhesus monkeys (Macaca mulatta) weighing between 6 and $10 \mathrm{~kg}$ were housed individually and allowed free access to water. The two male monkeys in the drug discrimination experiment were maintained at $85 \%$ of their free-feeding weights by regulating the number of Purina Monkey Chow biscuits they received daily. The four monkeys in the tail withdrawal experiments were allowed free access to food in the home cage. All monkeys received fresh fruit and vitamins occasionally.

\subsubsection{Drug discrimination procedure}

Drug discrimination experiments were conducted in sound-attenuated, ventilated isolation chambers equipped with two response levers located on either side of a food receptacle and within easy reach of a seated monkey. An array of stimulus lights was located directly above the response levers and a dispenser that could deliver food pellets was located outside the chamber.

Monkeys were seated in Plexiglas primate chairs during daily experimental sessions that lasted $2 \mathrm{~h}$ or less. Both monkeys had been trained to discriminate between s.c. injections of EKC $(0.0032$ $\mathrm{mg} / \mathrm{kg}$ ) and saline. The multiple-cycle training and testing procedures used in the present study have been described elsewhere (Bertalimo et al., 1982). Training sessions consisted of between two and six discrete $15 \mathrm{~min}$ cycles; each cycle consisted of a $10 \mathrm{~min}$ time-out period during which the chamber was dark and lever presses had no programmed consequence, and a 5 min response period during which the stimulus lights were illuminated and 100 consecutive responses on the injection-appropriate lever (left lever, EKC-appropriate; right lever, saline-appropriate) resulted in delivery of 10 Noyes $300 \mathrm{mg}$ banana-flavored pellets. When 100 correct responses were made within $5 \mathrm{~min}$, the stimulus lights were extinguished for the remainder of the response period. On some training days a single injection of EKC was administered prior to one of the cycles and that cycle was followed by a single non-injection (sham) cycle during which only responding on the EKCappropriate lever produced food. The number of saline injection cycles that preceded the EKC injection cycle varied across days and on some training days sham or saline was administered prior to all cycles.

Test sessions were identical to training sessions except that 100 consecutive responses on either level produced 10 food pellets, saline always was 
administered prior to the first cycle, and drug was administered prior to subsequent cycles. Increasing doses of drug were administered so that the cumulative dose increased by $1 / 2$ or $1 / 4 \log$ unit per cycle (Bertalimo et al., 1982).

\subsubsection{Tail withdrawal procedure and apparatus}

The tail withdrawal procedure used in the present study to measure antinociception was similar to that described previously (Dykstra and Woods, 1986). During weekly $3 \mathrm{~h}$ sessions, monkeys were restrained loosely at the neck and arms while seated in Plexiglas primate chairs. For tests of tail withdrawal latency, the lower $10-12 \mathrm{~cm}$ of the shaved tail was immersed in a thermos containing water at 40,50 or $55^{\circ} \mathrm{C}$. The latency until the tail was withdrawn from the thermos was recorded for each monkey at each temperature. If the tail was not withdrawn within $20 \mathrm{~s}$ (cut-off latency) the experimenter removed the tail from the thermos and a latency of $20 \mathrm{~s}$ was recorded.

Experimental sessions began with several exposures to $40^{\circ} \mathrm{C}$ water. Four monkeys were tested consecutively and the time between immersions for individual monkeys was $5 \mathrm{~min}$. It has been reported that $40^{\circ} \mathrm{C}$ water does not produce tail withdrawal in rhesus monkeys (Dykstra and Woods, 1986; Dykstra et al., 1987) and in the present study monkeys generally did not withdrawn their tails from $40^{\circ} \mathrm{C}$ water. However, if a monkey failed to keep its tail in $40^{\circ} \mathrm{C}$ water for $20 \mathrm{~s}$ on at least three of four immersions, that animal was not tested further. In the subsequent pre-test component tails were immersed in 40,50 and $55^{\circ} \mathrm{C}$ water. The order in which the three temperatures were presented varied among subjects. If the latencies for tail withdrawal in the pre-test component were at or near $20 \mathrm{~s}$ for $40^{\circ} \mathrm{C}$ water and less than $5 \mathrm{~s}$ for $55^{\circ} \mathrm{C}$ water, monkeys received the test compound.

The test was identical to the pre-test, except that monkeys received s.c. injections of drug 10 min prior to tail immersion. The time between immersions for individual subjects was $5 \mathrm{~min}$ and the order in which temperatures were presented varied among subjects and across cycles. The inter-injection interval was $30 \mathrm{~min}$ and a maximum of four doses were studied in a single session (i.e.
$2 \mathrm{~h}$ total time). The cumulative dosing procedure was similar to that described above.

\subsection{Receptor binding assays}

Guinea pig brain membranes were pretreated with the site directed acylating agents 2-(4ethoxybenzyl)-1-diethylaminoethyl-5-isothiocyanatobenzimidazole $\cdot \mathrm{HCl}$ (BIT) and $\mathrm{N}$-phenyl- $\mathrm{N}$ [1-(2-(4-isothiocyanato)phenethyl)-4-piperidinyl]propanamide $\cdot \mathrm{HCl}$ (FIT) to deplete the membranes of $\mu$ and $\delta$ receptors (Rothman et al., 1985). $\kappa$ Binding sites were labeled with both $\left[{ }^{3} \mathrm{H}\right] \mathrm{U} 69,593$ and $\left[{ }^{3} \mathrm{H}\right] \mathrm{BRM}$. The $\left[{ }^{3} \mathrm{H}\right] \mathrm{U} 69.593$ binding assay proceeded as previously described (Rothman et al., 1988b). Briefly, incubations were for $60 \mathrm{~min}$ at $37^{\circ} \mathrm{C}$ in $50 \mathrm{mM}$ Tris- $\mathrm{HCl}$, pH 7.4, containing $3 \mathrm{mM} \mathrm{MnCl} 2,0.1 \mathrm{mg} / \mathrm{ml}$ bovine serum albumin, and a protease inhibitor cocktail containing bacitracin $(100 \mu \mathrm{g} / \mathrm{ml})$, bestatin $(10 \mu \mathrm{g} / \mathrm{ml})$, leupetin $(4 \mu \mathrm{g} / \mathrm{ml})$, chymostatin $(2 \mu \mathrm{g} / \mathrm{ml})$ and captopril $(1 \mu \mathrm{g} / \mathrm{ml})$. Non-specific binding was defined using $1 \mu \mathrm{M}$ U69,593. The $\left[{ }^{3} \mathrm{H}\right] \mathrm{BRM}$ binding assay proceeded according to published protocols (Rothman et al., 1985), except that the assay was conducted without $\mathrm{NaCl}$. Nonspecific binding was defined using $1 \mu \mathrm{M}$ ( - )-bremazocine, $\left[{ }^{3} \mathrm{H}\right]\left[\mathrm{D}-\mathrm{Ala}^{2}\right.$,D-Leu $\left.{ }^{5}\right]$ enkephalin $\left(\left[{ }^{3} \mathrm{H}\right] \mathrm{DADL}\right)$ and $\left[{ }^{3} \mathrm{H}\right] 6 \beta$-fluoro-6-desoxy-oxymorphone $\left(\left[{ }^{3} \mathrm{H}\right] \mathrm{FOXY}\right)$ binding assays were conducted, using rat brain membranes, as previously described (Rothman et al., 1988a,c). In these assays, the non-specific binding was defined using $10 \mu \mathrm{M}$ levallorphan. Proteins were measured as described (Lowry et al., 1951).

Binding surfaces were generated and analyzed as previously described (Rothman et al., 1988d; Rothman, 1986). Briefly, two concentrations of ${ }^{3} \mathrm{H}$ ligand were each displaced by varying concentrations of test drugs. The combined data were fit to either a one site or two site binding model using MLAB (Knott et al., 1972) for the best-fit parameter estimates. MLAB fits the data according to a weighted non-linear least squares curve fitting algorithm.

\subsection{Chemicals}

$\left[{ }^{3} \mathrm{H}\right] \mathrm{FOXY} \quad(\mathrm{SA}=53 \mathrm{Ci} / \mathrm{mmol}),\left[{ }^{3} \mathrm{H}\right] \mathrm{DADL}$ $(\mathrm{SA}=46.9 \mathrm{Ci} / \mathrm{mmol})$ and $\left[{ }^{3} \mathrm{H}\right](-)$-bremazocine 
(specific activity $21.3 \mathrm{Ci} / \mathrm{mmol}$ ) were supplied by New England Nuclear Corp. $\left[{ }^{3} \mathrm{H}\right] \mathrm{U} 69,593$ (specific activity $40 \mathrm{Ci} / \mathrm{mmol}$ ) was purchased from Amersham Corp. The enantiomers of U50,488 were synthesized as described previously (De Costa et a1., 1987). The sources of the other chemicals can be found in previous publications (Rothman et al., 1988c).

\section{Results}

\subsection{Drug discrimination studies}

Monkeys trained to discriminate between s.c. injections of $0.0032 \mathrm{mg} / \mathrm{kg} \mathrm{EKC} \mathrm{and} \mathrm{saline} \mathrm{gener-}$ alized to $\mathrm{EKC}$ in a dose-related manner with the smallest dose of EKC that produced complete generalization being $0.0018 \mathrm{mg} / \mathrm{kg}$ (data not shown). (-)-(1S,2S)-U50,488 and (+)-(1R,2R)U50,488, ( \pm )-U50,488 and $( \pm)$-cis-I substituted completely for the EKC discriminative stimulus in that all four drugs produced responding exclusively in the EKC appropriate lever (fig. 1, left panel). The order of potency as discriminative stimuli was $(-)-(1 \mathrm{~S}, 2 \mathrm{~S})-\mathrm{U} 50,488>( \pm)-\mathrm{U} 50,488$ $>( \pm)$-cis-I $>(+)-(1 \mathrm{R}, 2 \mathrm{R})-\mathrm{U} 50,488$. At doses that produced EKC-appropriate responding, none of the drugs altered rates of lever pressing (data not shown). There was insufficient quantities of $(+)$ cis-I and (-)-cis-I for in vivo testing.

\subsection{Tail withdrawal}

The latency for tail withdrawal from 40,50 and $55^{\circ} \mathrm{C}$ water was temperature-dependent. The average latencies for tail withdrawal during pre-test components was $17.7,1.7$ and $1.3 \mathrm{~s}$ for 40,50 and $55^{\circ} \mathrm{C}$ water, respectively. Because the average latencies obtained with $40^{\circ} \mathrm{C}$ water were $>17 \mathrm{~s}$ during all pre-test components as well as during all test components, data with $40^{\circ} \mathrm{C}$ water are not
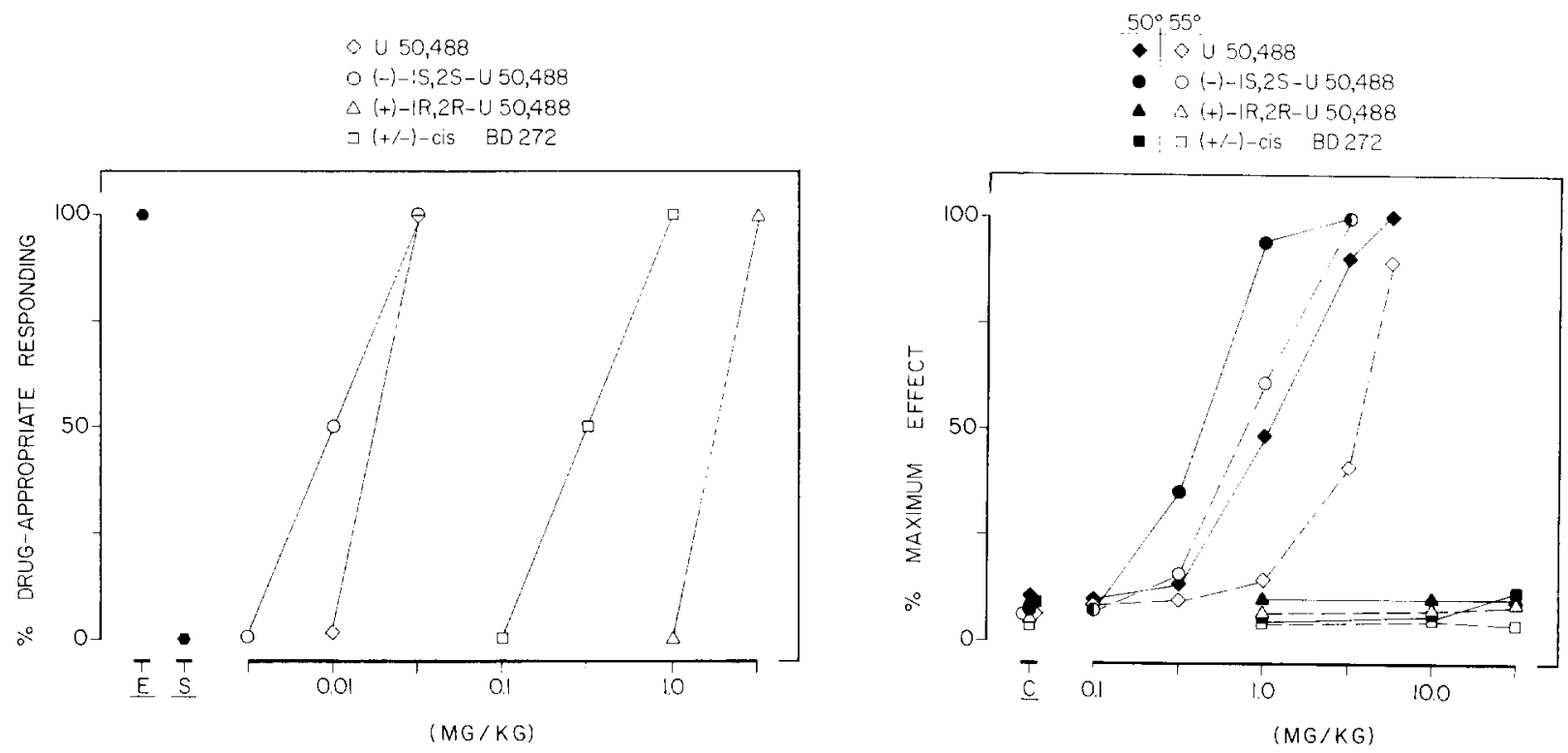

Fig. 1. Discriminative stimulus effects (left panel) and effects on tail withdrawal latencies (right panel) of U50,488 (diamonds), (-)-(1S,2S)-U50,488 (circles), (+)-1R,2R-U50,488 (triangles) and ( \pm )-cis-I (BD272) (squares). Ordinates: left panel, average percentage of responses on the ethylketocyclazocine (EKC) lever for two monkeys; right panel, average latency for tail withdrawal from $50^{\circ} \mathrm{C}$ (closed symbols) and $55^{\circ} \mathrm{C}$ (open symbols) water for four monkeys, expressed as a percentage of the maximum possible latency (i.e. $20 \mathrm{~s}$ ). Abscissas: both panels, dose in $\mathrm{mg} / \mathrm{kg}$ body weight. Points above $\mathrm{E}$ and $\mathrm{S}$ in the left panel represent discriminative stimulus effects of the training dose of EKC $(0.0032 \mathrm{mg} / \mathrm{kg})$ and saline, respectively. Points above $\mathrm{C}$ in the right panel represent the average latency for tail withdrawal from $50^{\circ} \mathrm{C}$ (closed symbols) or $55^{\circ} \mathrm{C}$ (open symbols) water prior to the administration of drug (pre-test component). 
shown. ( \pm )-U50,488 and (-)-(1S,2S)-U50,488 produced dose-related increases in tail withdrawal latencies from 50 and $55^{\circ} \mathrm{C}$ water (fig. 1, right panel). (-)-(1S,2S)-U50,488 was 2-4 times more potent than $( \pm)-U 50,488$ and both compounds were more potent as antinociceptive agents with $50^{\circ} \mathrm{C}$ water than with $55^{\circ} \mathrm{C}$ water. (+) $-(1 \mathrm{R}, 2 \mathrm{R})-$ U50,488 and ( \pm )-cis-I, up to a dose of $32.0 \mathrm{mg} / \mathrm{kg}$, failed to increase tail withdrawal latencies above pre-test values (triangles and squares, respectively, right panel, fig. 1). Limitations on the solubility of $(+)-(1 \mathbf{R}, 2 \mathrm{R})-\mathrm{U} 50,488$ and $( \pm)$-cis-I precluded administration of doses larger than $32.0 \mathrm{mg} / \mathrm{kg}$.

\subsection{Ligand binding data}

The relatively potent ability of ( \pm )-cis-I to substitute for EKC in the drug discrimination studies $\left(\mathrm{ED}_{50}\right.$ about $0.5 \mathrm{mg} / \mathrm{kg}$ ) and its virtual inactivity in the test for antinociception, led us to examine the interaction of $( \pm)$-cis-I and its enantiomers with $\kappa$ binding sites labeled by $\left[{ }^{3} \mathrm{H}\right] \mathrm{BRM}$ and $\left[{ }^{3} \mathrm{H}\right] \mathrm{U} 69,593$.

Binding surface analysis of the interaction of (-)-(1S,2S)-U50,488, (+)-(1R,2R)-U50,488 and (+)-tifluadom with $\left[{ }^{3} \mathrm{H}\right] \mathrm{BRM}$ binding revealed the existence of two binding sites distinguished by the inhibitory potency of $(-)-(1 \mathrm{~S}, 2 \mathrm{~S})-\mathrm{U} 50,488$ (fig. 2 , table 1). Whereas BRM had similar $\mathrm{K}_{\mathrm{d}} \mathrm{s}$ for
TABLE 1

Best-fit parameter estimates of the two site model. The binding surfaces reported in fig. 2 (78 data points) were fit to the two site competitive model. The best-fit parameter estimates are reported above, and generated the lines in fig. 2 . The sumof-squares was 0.152 . When the data were fit to a one site model, the sum-of-squares was 0.779 , which was significantly worse $(P<0.001)$. The binding parameters of $(-)-(1 S, 2 S)$ U50,488 and (+)-(1R,2R)-U50,488 were used to predict the displacement which would be observed for $( \pm)$-U50,488. As shown in in fig. $2 \mathrm{C}$, the lines generated by these binding parameters fit the observed data well. Each parameter value is \pm S.D.

\begin{tabular}{lll}
\hline Parameter & Site 1 & Site 2 \\
\hline $\begin{array}{l}\mathrm{B}_{\max } \\
(\mathrm{fmol} / \mathrm{mg}\end{array}$ \\
$\begin{array}{c}\text { protein }) \\
\text { Bremazocine } \\
\left(\mathrm{K}_{\mathrm{d}}, \mathrm{nM}\right)\end{array}$ & $172 \pm 17$ & $221 \pm 22$ \\
$(-)-(1 \mathrm{~S}, 2 \mathrm{~S})-\mathrm{U} 50,488$ & $0.46 \pm 0.10$ & $0.81 \pm 0.16$ \\
$\quad\left(\mathrm{~K}_{\mathrm{d}}, \mathrm{nM}\right)$ & $30.2 \pm 9.0$ & $10485 \pm 2831$ \\
$\begin{array}{c}(+)-(1 \mathrm{R}, 2 \mathrm{R})-\mathrm{U} 50,488 \\
\left(\mathrm{~K}_{\mathrm{d}}, \mathrm{nM}\right)\end{array}$ & $14568 \pm 4785$ & $4340 \pm 1196$ \\
$\begin{array}{c}+)-\mathrm{Tifluadom} \\
\left(\mathrm{K}_{\mathrm{d}}, \mathrm{nM}\right)\end{array}$ & $0.95 \pm 0.31$ & $112 \pm 27$ \\
\hline
\end{tabular}

both sites ( 0.46 and $0.81 \mathrm{nM}),(-)-(1 \mathrm{~S}, 2 \mathrm{~S})-\mathrm{U} 50,488$ had $\mathrm{K}_{\mathrm{d}} \mathrm{s}$ of 30.2 and $10485 \mathrm{nM}$ for site 1 and site 2 , respectively. ( +$)-(1 \mathrm{R}, 2 \mathrm{R})-\mathrm{U} 50,488$ bound to both sites with very low affinity. $(+)$-Tifluadom had $\mathrm{K}_{\mathrm{d}} \mathrm{s}$ of 0.95 and $113 \mathrm{nM}$ for site 1 and 2,
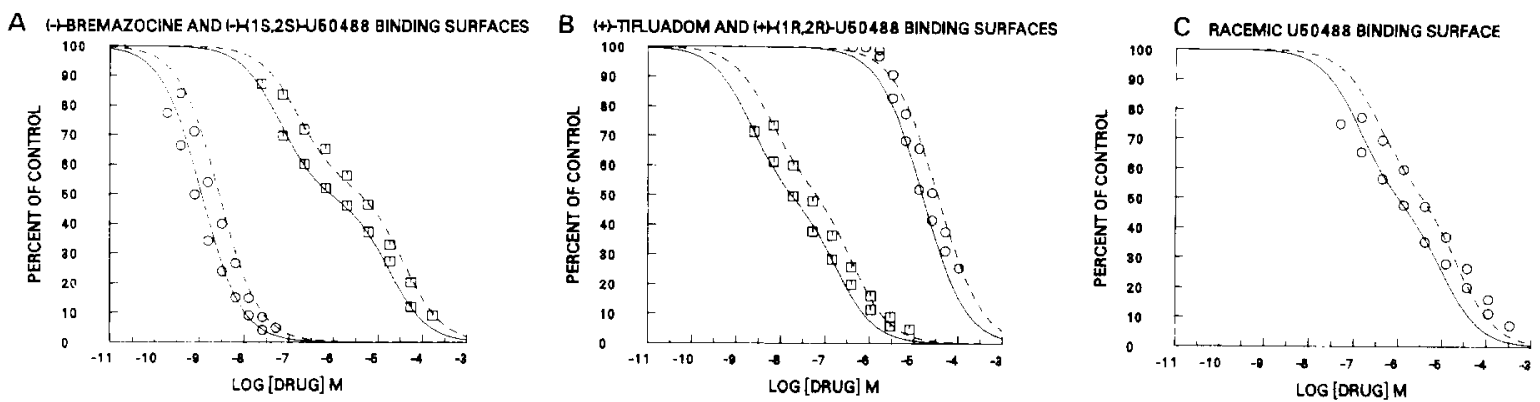

Fig. 2. (A) Two concentrations of $\left[{ }^{3} \mathrm{H}\right](-)$-bremazocine $(0.52$ and $2.1 \mathrm{nM})$ were each displaced by eight concentrations of (-)-bremazocine (circles) and (-)-(1S,2S)-U50,488 (squares). The solid and dashed lines are those predicted by the best-fit parameter estimates for the 0.52 and $2.1 \mathrm{nM}$ displacement curves (table 1). Each point is the mean of two determinations which differed by less than $10 \%$. (B) Two concentrations of $\left[{ }^{3} \mathrm{H}\right](-)$-bremazocine $(0.52$ and $2.1 \mathrm{nM})$ were each displaced by eight concentrations of $(+)-(1 \mathrm{R}, 2 \mathrm{R})-\mathrm{U} 50,488$ (circles) and (+)-tifluadom (squares). The solid and dashed lines are those predicted by the best-fit parameter estimates for the 0.52 and $2.1 \mathrm{nM}$ displacement curves (table 1). Each point is the mean of two determinations which differed by less than $10 \%$. (C) Two concentrations of $\left[{ }^{3} \mathrm{H}\right]$ bremazocine were each displaced by eight concentrations of $( \pm)-U 50,488$. The binding parameters of $(-)-(1 \mathrm{~S}, 2 \mathrm{~S})-\mathrm{U} 50,488$ and $(+)-(1 \mathrm{R}, 2 \mathrm{R})-\mathrm{U} 50,488$ were used to generate the lines in the figure. Each point is the mean of two determinations which differed by less than $10 \%$. 


\section{TABLE 2}

Interaction of ( \pm )-cis-I and its enantiomers with $\mu, \delta$ and $\kappa$ binding sites. (A) The ability of test drugs at a concentration of $1 \mu \mathrm{M}$ to inhibit the binding of $\left[{ }^{3} \mathrm{H}\right] \mathrm{BRM}(2.6 \mathrm{nM}),\left[{ }^{3} \mathrm{H}\right] \mathrm{DADL}(2.1 \mathrm{nM})$ and $\left[{ }^{3} \mathrm{H}\right] \mathrm{FOXY}(2.4 \mathrm{nM})$ to rat brain membranes is reported. The inhibitory potency $( \pm)$-cis-I $(1 \mu \mathrm{M})$ was also determined using $\left[{ }^{3} \mathrm{H}\right] \mathrm{BRM}$ to label $\kappa$ binding sites of guinea pig brain membranes. Each value is the mean of two determinations which differed by less than $5 \%$. (B) As described in Methods, $\left[{ }^{3} \mathrm{H}\right] \mathrm{U} 69,593(2.2 \mathrm{nM})$ was displaced by the enantiomers of $( \pm$ )-cis-l. The displacement curves were fit to the two parameter logistic equation (Rodbard et al., 1976) for the $\mathrm{IC}_{50}$, and the $\mathrm{K}_{\mathrm{i}}$ s calculated using the equation: $\mathrm{K}_{\mathrm{i}}=\mathrm{IC}_{50} /\left(1+1 / \mathrm{K}_{\mathrm{d}}\right)$. ${ }^{\mathrm{a}}$ The $\mathrm{K}_{\mathrm{i}} \mathrm{s}$ on the enantiomers of $\mathrm{U} 50.488$ reported in another publication (Rothman et al., 1988b) are included to facilitate comparison of the results.

\begin{tabular}{|c|c|c|c|c|}
\hline \multirow[t]{2}{*}{ (A) Drug $(1 \mu \mathrm{M})$} & \multicolumn{4}{|c|}{ Percent of control } \\
\hline & $\begin{array}{l}{\left[{ }^{3} \mathrm{H}\right] \mathrm{BRM}} \\
\text { (guinea pig) }\end{array}$ & $\begin{array}{l}{\left[{ }^{3} \mathrm{H}\right] \mathrm{BRM}} \\
\text { (rat) }\end{array}$ & $\begin{array}{l}{\left[{ }^{3} \mathrm{H}\right] \mathrm{DADL}} \\
\text { (rat) }\end{array}$ & $\begin{array}{l}{\left[{ }^{3} \mathrm{H}\right] \mathrm{FOXY}} \\
\text { (rat) }\end{array}$ \\
\hline$( \pm)$-Cis-I & 108 & 95 & 94 & 94 \\
\hline$(-)-(1 \mathrm{~S}, 2 \mathrm{~S})-\mathrm{U} 50,488$ & N.D. & 83 & 73 & 64 \\
\hline$(+)-(1 \mathrm{R}, 2 \mathrm{R})-\mathrm{U} 50,488$ & N.D. & 88 & 89 & 61 \\
\hline (B) Drug & $\mathrm{K}_{\mathrm{i}}(\mathrm{nM})$ & & & \\
\hline$(-)$-Cis-I & $167 \pm 4$ & & & \\
\hline$(+)$-Cis-I & $2715 \pm 130$ & & & \\
\hline$(-)-(1 S, 2 S)-U 50,488^{a}$ & $0.89 \pm 0.05$ & & & \\
\hline$(+)-(1 R, 2 R)-U 50,488^{a}$ & $299 \pm 16$ & & & \\
\hline
\end{tabular}

respectively. ( \pm )-U50,488 was a weak displacer of $\left[{ }^{3} \mathrm{H}\right] \mathrm{BRM}$ binding (fig. $2 \mathrm{C}$ ). The binding parameters obtained for $(-)-(1 \mathrm{~S}, 2 \mathrm{~S})-\mathrm{U} 50,488$ and $(+)$ $(1 \mathrm{R}, 2 \mathrm{R})-\mathrm{U} 50,488$ accurately predicted the $( \pm)-$ U50,488 binding surface. ( \pm )-Cis-I, at concentrations of $1 \mu \mathrm{M}$, failed to significantly inhibit $\left[{ }^{3} \mathrm{H}\right] \mathrm{BRM}$ binding (table $2 \mathrm{~A}$ ) using brain membranes prepared from either guinea pig or rat. $(+)$-Cis- 1 and (-)-cis-I at $1 \mu \mathrm{M}$ also failed to inhibit $\left[{ }^{3} \mathrm{H}\right] \mathrm{BRM}$ binding to guinea pig brain membranes (data not shown).

Other experiments tested the hypothesis that $( \pm$ )-cis-I might interact at $\mu$ or $\delta$ binding sites (table 2A). At a concentration of $1 \mu \mathrm{M}( \pm$ )-cis-I did not significantly inhibit either $\left[{ }^{3} \mathrm{H}\right] \mathrm{FOXY}$ or $\left[{ }^{3} \mathrm{H}\right]$ DADL binding. At $1 \mu \mathrm{M}$, both $(-)-(1 \mathrm{~S}, 2 \mathrm{~S})-$ U50,488 and (+)-(1R,2R)-U50,488 weakly inhibited $\left[{ }^{3} \mathrm{H}\right] \mathrm{DADL}$ binding, fairly potently inhibited (approximately $40 \%$ ) $\left[{ }^{3} \mathrm{H}\right] \mathrm{FOXY}$ binding, and consistent with the data reported in fig. 2 , weakly inhibited $\left[{ }^{3} \mathrm{H}\right] \mathrm{BRM}$ binding.

In contrast, initial experiments indicated that 1 $\mu \mathrm{M}( \pm)$-cis-I inhibited $\left[{ }^{3} \mathrm{H}\right] \mathrm{U} 69,593$ binding to guinea pig brain membranes. We therefore examined the interaction of (-)-cis-I and (+)-cis-I with $\left[{ }^{3} \mathrm{H}\right] \mathrm{U} 69,593$ binding. As reported in table $2 \mathrm{~B}$, these agents had apparent $\mathrm{K}_{\mathrm{d}} \mathrm{s}$ of 167 and
$2715 \mathrm{nM}$, respectively. Previous studies established that (-)-(1S,2S)-U50,488 and (+)-(1R,2R)U50,488 had apparent $\mathrm{K}_{\mathrm{d}}$ s of 0.89 and $299 \mathrm{nM}$, respectively (Rothman et al., 1988b). Thus the enantiomers of $( \pm)$-cis-I exhibit about the same degree of enantioselectively as the enantiomers of $\mathrm{U} 50,488$, but with $\mathrm{K}_{\mathrm{d}} \mathrm{s}$ about one order of magnitude higher.

\section{Discussion}

Although U50,488 (a racemic compound) has been used as a selective $\kappa$ agonist for several years, few studies have examined the pharmacological activity of its enantiomers, (-)-(1S,2S)-U50,488, $(+)-(1 \mathrm{R}, 2 \mathrm{R})-\mathrm{U} 50,488, \quad(-)$-cis-I and (+)-cis-I. The major finding of this paper is that the biological activity related to activation of $\kappa$ receptors by U50,488 appears to reside primarily in the (-)(1S,2S)enantiomer. In drug discrimination studies (fig. 1), (-)-(1S,2S)-U50,488 is about 100 times more potent than $(+)-(1 \mathrm{R}, 2 \mathrm{R})-\mathrm{U} 50,488$. Similarly, in a test of analgesia, whereas (-)-(1S,2S)U50,488 is active $\left(\mathrm{ED}_{50}\right.$ less than $\left.1 \mathrm{mg} / \mathrm{kg}\right),(+)$ $(1 \mathrm{R}, 2 \mathrm{R})-\mathrm{U} 50,488$ is virtually inactive. The racemate, U50,488, was active in both paradigms, 
having a potency intermediate between that of its two enantiomers.

An interesting finding to emerge from this study is that $( \pm)$-cis-I potently substituted for EKC in the drug discrimination experiments, yet was inactive in the tail withdrawal tests. This finding prompted the examination of the interaction of $( \pm)$-cis-I and its two enantiomers with $\mu, \delta$ and $\kappa$ binding sites in vitro. As described previously (Kosterlitz et al., 1981), we define a $\kappa$ binding site as the residual $\left[{ }^{3} \mathrm{H}\right] \mathrm{BRM}$ binding remaining after suppression of $\mu$ and $\delta$ binding sites.

Previous studies demonstrated that, using membranes depleted of $\mu$ and $\delta$ binding sites by pretreatment with the site-directed acylating agents BIT and FIT respectively, $\left[{ }^{3} \mathrm{H}\right] \mathrm{BRM}$ labels a population of non- $\mu$, non- $\delta$ binding sites with some of the characteristics of $\kappa$ receptors (Rothman et al., 1985). The experiments reported here demonstrate the resolution of two $\left[{ }^{3} \mathrm{H}\right] \mathrm{BRM}$ binding sites distinguished by the inhibitory potency of $(-)-(1 \mathrm{~S}, 2 \mathrm{~S})-\mathrm{U} 50,488$. The site sensitive to $(-)-(1 \mathrm{~S}, 2 \mathrm{~S})-\mathrm{U} 50,488\left(\mathrm{~K}_{\mathrm{d}}=31 \mathrm{nM}\right)$, is $44 \%$ of the total number of binding sites. This, and the observation that the $K_{d}$ of $(-)-(1 S, 2 S)-U 50,488$ for site 2 is about $10 \mu \mathrm{M}$, explains the low potency with which (-)-(1S,2S)-U 50,488 displaces $\left[{ }^{3} \mathrm{H}\right] \mathrm{BRM}$ binding from rat brain membranes pretreated with BIT and FIT (fig. 2C).

In contrast, (-)-(1S,2S)-U50,488 binds about ten times more potently to the population of non- $\mu$, non- $\delta$ binding sites labeled by $\left[{ }^{3} \mathrm{H}\right] \mathrm{U} 69,593\left(\mathrm{~K}_{\mathrm{d}}\right.$ about $2 \mathrm{nM})$. This, and the fact that pretreatment of membranes with the acylating agent 1S,2Strans-2-isothiocyanato-N-methyl-N-[2-(1-pyrrolidinyl)cyclohexylbenzeneacetamide (deschloro U50,488 isothiocyanate) (De Costa et al., 1989) completely eliminates $\left[{ }^{3} \mathrm{H}\right] \mathrm{U} 69,593$ binding without altering $\left[{ }^{3} \mathrm{H}\right] \mathrm{BRM}$ binding strongly suggests that $\left[{ }^{3} \mathrm{H}\right] \mathrm{U} 69,593$ and $\left[{ }^{3} \mathrm{H}\right] \mathrm{BRM}$ label different populations of $\kappa$ binding sites, at which (-)(1S,2S)-U50,488 and (+)-(1R,2R)-U50,488 exhibit similar degrees of enantioselectivity. Taken collectively, these data support the hypothesis that guinea pig brain has three subtypes of $\kappa$ binding sites, distinguished by the inhibitory potencies of (-)-(1S,2S)-U50,488.

Our hypothesis derives additional support from the ligand binding and autoradiographic data published by Nock and associates (Nock et al., $1988 \mathrm{a}, \mathrm{b})$ that $\left[{ }^{3} \mathrm{H}\right] \mathrm{U} 69,593$ and $\left[{ }^{3} \mathrm{H}\right]$ ethylketocyclazocine label different populations of $\kappa$ binding sites. Although Zukin et al. (1988) suggested that guinea pig brain $\kappa$ receptors are almost exclusively of the type sensitive to U50,488, our data suggest otherwise.

Both (-)-(1S,2S)-U50,488 and (+)-(1R,2R)U50,488 were equipotent in inhibiting $\left[{ }^{3} \mathrm{H}\right]$ FOXY to $\mu$ binding sites. This observation supports the observations (Von Voigtlander and Lewis 1988) that (+)-(1R,2R)-U50,488 might possess weak $\mu$ agonist activity, illustrating again how different stereoisomers of the same drug can possess different pharmacological activities (Ariëns, 1987; 1986).

$( \pm)$-Cis-I, ( + )-cis-I and ( - )-cis-I $(1 \mu \mathrm{M})$ failed in inhibit $\left[{ }^{3} \mathrm{H}\right] \mathrm{BRM}$ binding to guinea pig membranes (table $2 \mathrm{~A}, \mathrm{~B}$ ). For this reason we did not examine further the interactions of $(-)$-cis-I or (+)-cis-I. ( \pm )-Cis-I did inhibit $\left[{ }^{3} \mathrm{H}\right] \mathrm{U} 69,593$ binding (data not shown). Additional experiments demonstrated that (-)-cis-I and (+)-cis-I had $\mathrm{K}_{\mathrm{d}}$ s of about 167 and $2700 \mathrm{nM}$ for the population of $\kappa$ receptors labeled by $\left[{ }^{3} \mathrm{H}\right] \mathrm{U} 69,593$. The $\mathrm{K}_{\mathrm{d}}$ of $(-)$-cis-I was intermediate between that of $(-)$ (1S,2S)-U50,488 (0.89 $\mathrm{nM})$ and (+)-(1R,2R)U50,488 (299 $\mathrm{nM})$, consistent with the intermediate potency of $( \pm)$-cis-I observed in the drug discrimination studies. These in vitro results suggest that the discriminative cue is mediated by the population of $\kappa$ receptors labeled by $\left[{ }^{3} \mathrm{H}\right] \mathrm{U} 69,593$. However, it is still necessary to show that this effect is naloxone reversible. Because $(-)$-cis-I and $(+)$-cis-I bind with reasonably high affinity to haloperidol-sensitive $\sigma$ binding sites $\left(\mathrm{K}_{\mathrm{d}} \mathrm{s}\right.$ of 81 and $221 \mathrm{nM}$, respectively), it remains a remote possibility that this binding site is involved in the pharmacological actions of the cis-enantiomers of U50,488 observed in this study (De Costa et al., in press).

The failure of $( \pm)$-cis-I to produce antinociception might be taken as evidence that different populations of $\kappa$ receptors mediate the discriminative cue and antinociception. However, (+)$(1 \mathrm{R}, 2 \mathrm{R})-\mathrm{U} 50,488$ was also inactive in the tailwithdrawal test, which is consistent with the observation that all compounds tested in this study 


\section{TABLE 3}

Summary of results. The pharmacological data reported in this study are summarized and compared with the $\mathrm{K}_{\mathrm{d}} \mathrm{s}$ of test drugs for the $\kappa$ binding site labeled by $\left[{ }^{3} \mathrm{H}\right] \mathrm{U} 69,593$. ${ }^{\text {a }}$ These $\mathrm{K}_{\mathrm{d}}$ values were calculated using the binding parameters obtained for the enantiomers (table $2 \mathrm{~B}$ ).

\begin{tabular}{|c|c|c|c|c|}
\hline \multirow[t]{3}{*}{ Drug } & \multicolumn{4}{|c|}{$\mathrm{ED}_{50}(\mathrm{mg} / \mathrm{kg})$} \\
\hline & \multirow{2}{*}{$\begin{array}{l}\text { Drug } \\
\text { discrimi- } \\
\text { nation }\end{array}$} & \multicolumn{2}{|c|}{ Antinociception } & \multirow[t]{2}{*}{$\mathrm{K}_{\mathrm{d}}(\mathrm{nM})$} \\
\hline & & $50^{\circ} \mathrm{C}$ & $55^{\circ} \mathrm{C}$ & \\
\hline$( \pm)-U-50,488$ & 0.018 & 0.98 & 2.72 & $1.8^{a}$ \\
\hline$( \pm)$-Cis-I & 0.32 & inactive & inactive & $314^{a}$ \\
\hline \multicolumn{5}{|l|}{$(-)-(1 \mathrm{~S}, 2 \mathrm{~S})-$} \\
\hline U 50,488 & 0.01 & 0.36 & 0.79 & 0.89 \\
\hline \multicolumn{5}{|l|}{$(+)-(1 \mathrm{R}, 2 \mathrm{R})-$} \\
\hline U50,488 & 1.8 & inactive & inactive & 299 \\
\hline
\end{tabular}

were ten to a hundred times more potent in the drug discrimination experiments than in the tests of analgesia. A more likely explanation for these observations is that the discriminative cue is activated at low fractional occupancy of the $\kappa$ receptor, whereas higher fractional occupancy is required to produce antinociception.

Taken collectively, the results reported here, and summarized in table 3 , suggest that the $\kappa$ receptor-related pharmacological activity of U50,488 resides primarily in the (-)-(1S,2S)-enantiomer, and that $(+)-(1 \mathrm{R}, 2 \mathrm{R})-\mathrm{U} 50,488 \mathrm{might}$ possess weak activity at $\mu$ receptors, consistent with data published by Von Voigtlander and Lewis (1988). Examination of the interaction of the four stereoisomers of U50,488 with the population of non- $\mu$, non- $\delta$ binding sites labeled by [ ${ }^{3} \mathrm{H}$ ]BRM and those labeled by $\left[{ }^{3} \mathrm{H}\right] \mathrm{U} 69,593$ provides further evidence for the existence of at least three classes of $\kappa$ binding sites in guiea pig brain, and suggest that the pharmacological actions of U50,488 result from activation of the $\kappa$ receptor labeled by $\left[{ }^{3} \mathrm{H}\right] \mathrm{U} 69,593$. The structure-activity profile and functional significance of the $\kappa$ binding sites labeled by $\left[{ }^{3} \mathrm{H}\right] \mathrm{BRM}$ are currently under investigation.

\section{References}

Ariëns, E.J., 1986, Stereochemistry: a source of problems in medicinal chemistry, Med. Res. Rev. 6, 451.
Ariëns, E.J., 1987, Stereochemistry in the analysis of drug-action. Part II, Med. Res. Rev. 7, 367.

Bertalimo, A.J., S. Herling, R.Y. Hampton, G. Winger and J.H. Woods, 1982, A procedure for the rapid evaluation of the discriminative stimulus effects of drugs, J. Pharmacol. Meth. 7, 289.

De Costa, B.R., W.D. Bowen, S.B. Hellewell, C. George, R.B. Rothman, A.A. Reid, J.M. Walker, A.E. Jacobson and K.C. Rice, Alterations in the stereochemistry of the kappa-selective agonist $\mathrm{U} 50,488$ result in high affinity sigma ligands, $\mathrm{J}$. Med. Chem. (in press).

De Costa, B.R., C. George, R.B. Rothman, A.E. Jacobson and K.C. Rice, 1987, Synthesis and absolute configuration of optically pure enantiomers of a kappa opioid receptor agonist. FEBS Lett. 223, 335.

De Costa, B.R., R.B. Rothman, V. Bykov, A.E. Jacobson and K.C. Rice, 1989, Selective and enantiospecific acylation of $\kappa$ opioid receptors by (1S,2S)-trans-2-isothiocyanato-N. methyl-[2-(1-pyrrolidinyl)cyclohexyl]benzeneacetamide. Demonstration of $\kappa$ receptor heterogeneity, J. Med. Chem. 32, 281.

Dykstra, L.A., D.E. Gmerek, G. Winger and J.H. Woods, 1987. Kappa opioids in rhesus monkeys: I. Diuresis, sedation, analgesia, and discriminative stimulus effects, J. Pharmacol. Exp. Ther. 242, 413.

Dykstra, L.A. and J.H. Woods, 1986, A tail withdrawal procedure for assessing analgesic activity in rhesus monkeys, $\mathrm{J}$. Pharmacol. Meth. 15, 763.

Hall, E.D., D.L. Wolf, J.S. Althaus and P.F. Von Voigtlander, 1987, Beneficial effects of the kappa opioid receptor agonist U-50488H in experimental acute brain and spinal cord injury, Brain Res. 435, 174.

Knott, G.D. and D.K. Reece, 1972, MLAB: a civilized curve fitting system, Proceedings of the Online 1972 International Conference 1, 497 (Abstract).

Kosterlitz, H.W., S.J. Paterson and L.E. Robson, 1981, Characterization of the kappa-subtype of the opiate receptor in the guinea pig brain, Br. J. Pharmacol. 73, 939.

Lahti, R.A., M.M. Mickelson, J.M. McCall and P.F. Von Voigtlander, 1985, $\left[{ }^{3} \mathrm{H}\right\} \mathrm{U}-69,593$, a highly selective ligand for the opioid $\kappa$ receptor, European J. Pharmacol. 109, 281.

Leander, J.D., 1983, A kappa opioid effect. Increased urination in the rat, J. Pharmacol. Exp. Ther. 224, 89.

Lowry, O.H., B.H. Rosenbrough, A.L. Farr and P.J. Randall, 1951, Protein measurement with the Folin phenol reagent, J. Biol. Chem. 193, 265.

Nock, B., A. Rajpara, L.H. O'Connor and T.J. Cicero, 1988a, Autoradiography of $\left[{ }^{3} \mathrm{H}\right] \mathrm{U}-69593$ binding sites in rat brain: Evidence for $\kappa$ opioid receptor subtypes, European $\mathrm{J}$. Pharmacol. 154, 27.

Nock, B., A. Rajpara, L.H. O'Connor and T.J. Cicero, 1988b, $\left[{ }^{3} \mathrm{H}\right] \mathrm{U}-69593$ labels a subtype of kappa opiate receptor with characteristics different from that labeled by $\left[{ }^{3}\right.$ H] ethylketocyclazocine, Life Sci. 42, 2403.

Pfeiffer, A., V. Brantl, A. Herz and H.M. Emrich, 1986, Psychotomimesis mediated by kappa opiate receptors, Science 233, 774. 
Porreca, F. and F.C. Tortella, 1987, Differential antagonism of mu agonists by U50488 $\mathrm{H}$ in the rat, Life Sci. 41, 2511.

Rodbard, D., R.H. Lenox, L. Wray and D. Ramseth, 1976. Statistical characterization of the random errors in the radioimmunoassay dose-response variable, Clin. Chem. 22 , 350.

Rothman, R.B., 1986, Binding surface analysis: an intuitive yet quantitative mehtod for the design and analysis of ligand binding studies, Alcohol Drug Res. 6, 309.

Rothman, R.B., V. Bykov, J.A. Danks, A.E. Jacobson, T.R. Burke, Jr., K.C. Rice and M. Herkenham, 1985, Preparation of rat brain membranes highly enriched with opiate kappa binding sites using site-directed alkylating agents: optimization of binding conditions, Neuropeptides 6, 503 .

Rothman, R.B., V. Bykov, D. Ofri and K.C. Rice, 1988a, LY164929: a highly selective ligand for the lower affinity $\left[{ }^{3} \mathrm{H}\right] \mathrm{D}$-ala ${ }^{2}$-D-Leu ${ }^{5}$-enkephalin binding site, Neuropeptides $11,13$.

Rothman, R.B., V. Bykov, A. Reid, B.R. De Costa, A.H. Newman, A.E. Jacobson and K.C. Rice, 1988b, A brief study of the selectivity of norbinaltorphimine, (-)cycloFOXY, and (+)-cycloFOXY among opioid receptor subtypes in vitro, Neuropeptides $12,181$.

Rothman, R.B., V. Bykov, K.C. Rice, A.E. Jacobson, G.N Kooper and W.D. Bowen, 1988c, Tritiated-6-beta-fluoro-6desoxy-oxymorphone $\left(\left[{ }^{3} \mathrm{H}\right] \mathrm{FOXY}\right)$ : a new ligand and pho- toaffinity probe for the $\mu$ opioid receptors, Neuropeptides $11,1$.

Rothman, R.B., J.B. Long, V. Bykov, A.E. Jacobson, K.C. Rice and J.W. Holaday, 1988d, Beta-FNA binds irreversibly to the opiate receptor complex: in vivo and in vitro evidence, J. Pharmacol. Exp. Ther. 247, 405.

Sheldon, R.G., L. Nunan and F. Porreca, 1987, Mu antagonist properties of kappa agonists in a model of rat urinary bladder mortility in vivo, J. Pharmacol. Exp. Ther. 243, 234.

Von Voigtlander, P.F., E.D. Hall, M.C. Ochoa, R.A. Lewis and H.J. Triezenberg, 1987, U-54494A: a unique anticonvulsant related to kappa opioid agonists, J. Pharmacol. Exp. Ther. $243,542$.

Von Voigtlander, P.F., R.A. Lahti and J.H. Ludens, 1983, U-50,488H: a selective and structurally novel non-mu (kappa) opioid agonist, J. Pharmacol. Exp. Ther. 224, 7.

Von Voigtlander, P.F. and R.A. Lewis, 1988, Analgesic and mechanistic evaluation of spiradilone, a potent kappa opioid, J. Pharmacol. Exp. Ther. 246, 259.

Zukin, R.S., M. Eghbali, D. Olive, E.M. Unterwald and A. Tempel, 1988, Characterization and visualization of rat and guinea pig brain kappa opioid receptors: evidencefor $\kappa_{1}$ and $\kappa_{2}$ opioid receptors, Proc. Natl. Acad. Sci. U.S.A. 85, 4061 . 